\title{
Semiotics in Wayang Topeng Tengger Show
}

\author{
Resdianto Permata Raharjo \\ Universitas Negeri Surabaya \\ rezdyraharjo@gmail.com
}

\author{
Setyo Yuwana Sudikan \\ Universitas Negeri Surabaya \\ setyayuwana@unesa.ac.id
}

\author{
Budi Nuryanta \\ Universitas Negeri Surabaya \\ budinuryanta@unesa.ac.id
}

\begin{abstract}
This study aims to find and describe signs and their meaning contained in Wayang Topeng Tengger show. Wayang Topeng Tengger is the art of wayang performances by people who wear masks. Although performed by people, the people only dance based on the role of the character they play and do not make any dialogue one another. The puppet plays a very important role, namely narrates the story or plays with dialogues or narratives. Wayang Topeng Tengger contains many signs, which include icons, indices, and symbols. The icon consists of three types, i.e. the topology icon, the diagrammatic icon, and the metaphor icon. The results of this study contribute to the science of culture in general and semiotics in particular as well as a medium of excavation, preservation and development of Wayang Topeng Tengger show art.
\end{abstract}

Keywords—wayang topeng Tengger, semiotics, icons, indices, and symbols.

\section{INTRODUCTION}

Tengger mountain region has a beautiful natural diversity and a very interesting culture that is still preserved by the people of Tengger. The people of Tengger still retain their culture and beliefs although they live in the era of technology. Tengger mountain is famous for its natural beauty. Even, the natural beauty of Tengger panorama becomes an icon of national and international tourism [1-3].

Moreover, Tengger ethnics have a variety of interesting and unique cultures. Tengger culture has similarities with Javanese culture in general, such as belief in spirit and life cycle ceremonies such as birth, death, and exorcism ritual. Tengger ethnicity is the descendant of Javanese community of Majapahit [4-6]. (Purnama and Rachmadian, 2016: 8; Sutarto, 2006: 4; Bahrudin, Masrukhi, and Atmaja, 2017: 21).

The beauty of natural scenery and the treasures of culture of the Tengger ethnic group do not solely belong to the Tengger community, but is a cultural richness of Indonesian that can enrich the repertoire of nature and culture of Indonesian society [7-9].

One of the cultural treasures that is very interesting is Wayang Topeng Tengger. Wayang Topeng Tengger is different from Wayang Kulit Purwa in Jawa, Wayang Kulit Sasak in Lombok, and wayang in Bali. Wayang Topeng Tengger is the art of wayang show whose character is human who wear mask. Although performed by people, the people only dance based on the role of the character they play and do not make any dialogue one another. The character only dance in accordance with the contents of the story told by the puppet.
Wayang Topeng Tengger has a resemblance to Wayang Wong and Wayang Topeng in Malang [10-11]

The existence of Wayang Topeng Tengger is located in Wonokerso Village, Sumber Subdistrict, Probolinggo Regency. Today, Wayang Topeng Tengger still exist in the midst of the development of society in the era of technology. The function of Wayang Topeng Tengger is as entertainment and media for exorcism ritual. Wayang Topeng Tengger show is mystical and sacred and cannot be performed at any time and event [12].

Wayang Topeng Tengger show is based on myths of mount Bromo and Bethara Kala. The play of Bethara Kala contains many symbolic, mystical, and cultural values. Therefore, Wayang Topeng Tengger show is studied using semiotic, mystical, and cultural values.

Semiotics is a term put forward by Charles Sanders Peirce. Semiology is the study of signs that have two-sided entities about signs and markers and meanings [13-16]. Semiotics is the study of signs and their meanings. Any sign of both verbal and nonverbal can be interpreted to find its meaning. According to Pierce semiotic includes three aspects, namely icons, indices, and symbols.

In Wayang Topeng Tengger show, there are many signs. Signs are a means of communication between two people to communicate or express something. Signs involve three aspects working together that cannot be separated, namely signs, objects, and interpretations. Signs can serve as the representative of something or someone in a certain capacity because of the representation of the relationship which is chained to an interpretation. A sign will be defined by another sign and so on [17-18]. According to Pierce (Sahid) the sign refers to something called an object. The relationship between the sign with its reference is divided into three, namely icon, index, and symbol [19].

An icon is a sign whose reference has a similarity relationship. The icons can be classified into three, namely (1) typology icons, i.e. marks referring to special resemblances, such as maps and fashion sketches (2) diagrammatic icons, i.e. marks of relational resemblance, for example, in official meetings, seating is organized by social status, and (3) a metaphorical icon, i.e. a sign that does not show any resemblance between a sign with its reference. The resemblance is not a sign and its reference, but between two references referred by the same sign. An example of a "mouse deer" sign refers directly to a mouse deer as animals and clever humans. Both references have the same characteristic, i.e. ingenious [20].

A symbol is a sign that has a relationship to its reference and has been conventionally established. Moreover, there has 
been an agreement among the users regarding the sign and its relationship to its reference [21]. Each symbol has a broad meaning depending on the socio cultural context of society and the readers because the meaning does not merely lie in the text, but lies in the one who interprets the text. In interpreting the text, the readers are influenced by the sign of the language, literature, and socio cultural context of society.

\section{RESULTS AND DISCUSSIONS}

Wayang Topeng Tengger Show contains a lot of semiotic, mystical, and cultural values. Semiotics is a science that learns the signs and their meanings. Semiotics includes indices, icons, and symbols. These three aspects will be explained one by one as follows:

In Wayang Topeng Tengger show there is semiotics. Semiotics according to Peirce includes three types, namely icons, indices, and symbols. When the semiotic species are described one by one, it is as follows:

\section{1) Icons}

The icon includes three types: (1) typology (e.g. mountain, cattle, vegetable), (2) diagrammatic icons (e.g. Sang Penguasa Jagad Sang Hyang Pikulun Sas Sis, Sang Hyang Punggung, Sang Hyang Pongat, Sang Hyang Lesmana Dewa, Sang Hyang Manikmaya), (2) a metaphorical icon (e.e. such as Sang Hyang Punggung kissing through the story of jayengkaton that the heritage of budama is near Mount Semeru). He immediately chased, Sang Hyang Lesmana Dewa managed to catch the heirloom at the peak of Merapi. But because he mistakenly held with his left hand the heirlooms suddenly disappear from the grip of Sang Hyang Lesmana Dewa.

\section{a. Icon of typology}

Typology icon is a sign that refers to special resemblances, such as maps and fashion sketches. As the mountain implies that the Tengger area is a mountainous area. Its inhabitants live in the area of the mountains, filled with steep soil, the slope is very sharp to the depth of $500-1000 \mathrm{~m}$. The road is narrow, sometimes rising with altitudes of up to 90 degrees. Sometimes it drops and turns very sharply. However, the area is very fertile and very suitable planted with vegetables such as potatoes, cabbage, onion, carrots, and tomatoes.

Ox means the symbol of Mahesa Sura, the son of Jaka Seger and Rara Anteng who lives and controls Mount Semeru. He has a pet animal in the form of a very dark calf which is very fat and very strong as the mount of Mahesa Sura.

Vegetables is as a symbol of livelihood and the main crop of Tengger people inhabiting Mount Bromo which are vegetables, such as potatoes, cabbage, onion, and carrots [22].

\section{b. The diagrammatic icon}

The diagrammatic icon is a sign that has a relational resemblance, for example in a formal meeting the seat is arranged by its social status. Sang Penguasa Jagad Sang Hyang Pikulun Sas Sis is a diagrammatic icon. Sang Penguasa Jagad Sang Hyang Pikulun Sas Sis refers to the creator and ruler of the highest world. The data implies that no power is more powerful or higher than Sang Penguasa Jagad Sang Hyang Pikulun Sas Sis. He is the sole and supreme ruler. It looks at the data as follows:

A puppet begins performances by telling the meeting of Sang Penguasa Jagad Sang Hyang Pikulun Sas Sis with His four sons namely; Sang Hyang Punggung, Sang Hyang
Pongat, Sang Hyang Lesmana Dewa, Sang Hyang Manikmaya. It was told that Sang Hyang Sas Sis is discussing the succession of the leadership of the heaven. Whoever of the four sons who are presented can bring home the heirlooms of Budama that deliberately cast by Sang Hyang at Pawenang, then he is entitled to replace the position of Pikulun at Pawenang as the ruler of the universe [23].

Based on the data, it is clear that Penguasa Jagad Sang Hyang Pikulun Sas Sis is the single most powerful ruler in this world. He is discussing the succession of world leadership with his four sons. Penguasa Jagad Sang Hyang Pikulun Sas Sis is a sign of a very democratic ruler, so to replace himself he does not appoint one of his children, but make a contest. Any one of his four sons who can bring back the heritage of Budama to heaven, he is the right to replace as ruler of this world.

\section{c. Metaphoric icons}

A metaphorical icon is a sign that shows no resemblance between a sign with its reference. The resemblance is two references referred to by the same sign [24]. The data of Klambi Limar Kinanti and Sabak Sakti Daludamana and Data "Klambi Limar Kinanti" refer to the colorful black-and-white boxes patterns jarit which means for Semar to serve the good, clean and honest people of Pandawa Lima (Punta Dewa, Bima, Janaka, Nakula, and Sadewa). The sign of "Klambi Limar Kinanti" has no resemblance to its reference, but has a second resemblance of having a clean trait.

Data of Sabuk Sakti Daludamana is the sign of a calm country. When the belt of Sakti Daludamana is loose, then the country is unstable. In contrast, if the Belt of Sakti Daludamana is tight, then the country is strong and stable. This looks at the data as follows:

Sang Hyang Lesmana Dewa runs to attack Sang Hyang Manikmaya to take revenge. But his fate is the same as his two older siblings and is said to be the God Wirati aka Kyai Semar Bojagati Nayantaka. Equipped with Klambi Limar Kinanti clothing and magic belt Daludamana. If the belt of Semar is loose, then the country is unstable, on the contrary, if it is tight then the country is stable. Semar was told to be imprisoned in Mount Gamping and when it was finished, he was ordered to go to Klampisireng and become Pandawa's guardian. He was given a white dove as the vehicle by Sang Hyang Manikmaya [25].

The data contains a metaphorical icon, i.e. the white dove. The data has no resemblance to the reference. It means goodness and purity. Semar is as a sign of a sacred figure, then the vehicle must also be sacred which is symbolized as a white dove.

\section{2) Index}

Index is a sign that has a close relationship with the reference, e.g. the data of Sang Hyang Punggung kissing through the jangengkaton story that the heritage of budama is near Mount Semeru. He immediately pursued [26].

The data indicate that the character of Sang Hyang Punggung have supernatural powers or extraordinary ability to know the existence of something through his mind's eye. Though he senses he does not see the existence of the heritage of Budama. However, he can see the existence of the heirloom Budama through supernatural power or intelligence. This can be seen in the data as follows: "The four sons of Pikulun Sas 
Sis rushed to seek magical heirlooms Budama as a precondition to occupy the throne of the God. Sang Hyang Punggung kissed through the story of jayengkaton that the heirloom is near Mount Semeru. He immediately pursued "[27].

Based on these data Sang Hyang Punggung has the ambition to be able to replace his father and has extraordinary cleverness. He does not have a good strategy and has no patience in achieving his ideals to replace his father's power. The word "rushed" contains the meaning of Sang Hyang Punggung who is eager or ambitious to immediately be able to bring heirlooms Budama into heaven to soon be able to replace the power of his father as the ruler of this world.

On the contrary, his brother named Sang Hyang Manikmaya, has patience and has a good strategy. He was not in a hurry to get the heirlooms of Budama, but instead he meditated and prayed inwardly for his mother's approval. He finally got a divine inspiration or sasmita / magic sign to meditate in the forest of turban in Goa Paseban Gandamayit. Finally he was the one who managed to find and bring heirloom Budama to the heaven and successfully replace the position of his father as the ruler of this world. This looks at the data as follows:

Different from his three siblings who seem to hurry / full of lust to get heirloom Budama, the fourth son of Pikulun Sas Sis that is Sang Hyang Manikmaya take a different strategy. He calls his mother's name (nyambat) and asks inner blessing. Suddenly he gets sasmita / supernatural signs to meditate in the forest of the turban siluman, turban = udeng / headband, siluman $=$ spirits. Precisely in the cave Paseban Gandamayit [28].

In short, Sang Hyang Manikmaya was received with joy by Pikulun Sas Sis because he managed to get heirloom Budama. Next, he was told to wash his body and was given white clothes as a sign of God clothes as a symbol of sacred people. Sang Hyang Manikmaya was eventually appointed as God replacing his father and was given the title of Bethara Guru and became the head of the Gods in the heaven. Bethara Guru was given advice by his father, "Don't be arrogant. Don't be disrespectful to a poor women who will come to him and become his soul mate [29].

Based on the data it can be concluded that to achieve the ideals, people must be patient, should not be in a hurry, and should not achieve the ideals in ways such as killing others and even his own brother. The data also shows that goodness can defeat evil.

\section{3) Symbols}

Wayang Topeng Tengger performance contains many symbols, like Dara Putih. Dara Putih is a symbol which contains sainthood and goodness. The symbol of Dara Putih contains many conventionally-agreed means by almost of the citizens. Those who will employ sainthood and goodness use this term as well.

Bethara Guru is a symbol which symbolizes the head of the god who can't resist his passions when he is with the beautiful woman, Nagagini. As a result, his semen came out and eventually became a Bathara Kala.

Bathara Kala is also a symbol of criminal. It is a symbol of an illegitimate child who is not recognized by his father that is Bathara Guru because Bathara Kala was not born from his mother's womb. It happened because the Bethara guru's semen came out as he is unable to resist his lust when he is with Nagagini. Bathara Guru won't recognize Bathara kala as his son. However, when Bethara Kala was looking for his parents, he coincidentally met Bethara Narada who told him that Bethara Kala's father is Bethara guru and his mother is Nagagini. Bethara Kala met Bethara Guru and Nagagini. However Betara Guru insists that he did not want to recognize that Bathara Kala is his son. Bathara Kala forced Bathara Guru to recognize him as his son. In the end, Bathara Guru recognized Bathara Kala as his son with a condition that he must ascetic at the peak of B29 (a well known place in Bromo Mountain) and he would get a Keris named Budama. Bethara kala at the time was able to fulfill Bethara Guru's requirement.

Betari Durga is a symbol which contains meaning that she was a beautiful angel and was a Bethara Guru's wife (A leader of gods). Unfortunately, her character was bad. She, as a mother could not properly educate her son named Bethara Kala. Allowing his son's lust to eat human, like an only-child, child who is flanked by shower, child who walks in the noon. It is resulted that Bethara Guru cursed her to be an ugly bad giant woman and became a queen of the devil. That thing can be seen as in the following: "Nagagini was scolded by Bethara Guru because she doesn't stop the bad deeds and eventually cursed to be Bethari Durga and is staying at Kahyangan Dandang Manguri as a queen of devils" [30]. Based on the above data, Bethari Durga is a symbol of a bad woman and is a queen of devils. She was actually a pretty woman and the wife of god's leader; however she has done many bad things. As a result, she was cursed by Bethara Guru to be Bethari Durga, an ugly angel who has a giant face.

\section{CONCLUSION}

Based on the above description, it is concluded that Wayang Topeng Tengger show is a Wayang's performance which employs mask during its show. Even though the characters are human being, they do not do any conversation at all during the show. The characters only perform dancing based on the figures played and follow the story that is told by Dalang. Wayang Topeng holds very important roles in telling the plot of the story either in narrative way or dialogue one. Wayang Topeng Tengger Show contains many signs. The signs in Wayang Topeng Tengger show includes three aspects namely icons, indices, and symbols. Icon consists of three types; they are typology icon, dramatic icon and metaphoric icon. The Typology icon is like mountains, ox, and vegetables. The dramatic icon is like the position of Sang Hyang Sas Sis with his four children. The metaphoric icon is like Klambi Limar Kinanti, Sabuk Sakti Daludamana and the white dove. Index is a sign which has such relationship with its references. Symbol is a sign which has close relationship with its reference that is formed conventionally. There is no agreement between the sign user and connection of sign and its references.

\section{REFERENCES}

[1] A. Sutarto, Sekilas Tentang Masyarakat Tengger. Makalah disampaikan pada acara pembekalan Jelajah Budaya 2006 yang diselenggarakan oleh Balai Kajian Sejarah dan Nilai Tradisional Yogyakarata, August, 2006.

[2] Lisnasari and Sukmawan. (2016). Berhulu Welasasih Pepitu, Bermuara Narasi Arkadia: Kajian Ekokritik Cerita Rakyat Tengger. Jurnal Ilmiah Edukasi \& Sosial, Volume 7, 2016. pp 167-176.

[3] Listiyana and Mutiah. (2017). Pemberdayaan Masyarakat Suku Tengger Ngadas Poncokusumo Kabupaten Malang dalam Mengembangkan Potensi Tumbuhan Obat dan Hasil Pertanian Berbasis 
"Etnofarmasi" Menuju Terciptanya Desa Mandiri. Jurnal of Islamic Medicine, Volume 1 (1), 2017. pp. 1-8.

[4] Y.P. Purnama, Pengaruh Masuknya Budaya Asing Terhadap Pelestarian Kebudayaan tari Tradkisional Wayang Topeng Malang di Malang Raya, Jawa Timur. Pesona, Vol.2, 2016.

[5] A. Sutarto, Sekilas Tentang Masyarakat Tengger. Makalah disampaikan pada acara pembekalan Jelajah Budaya 2006 yang diselenggarakan oleh Balai Kajian Sejarah dan Nilai Tradisional Yogyakarata, August, 2006.

[6] M. Bahrudin, and Atmaja, Mistik dan Politik: Praktik Perdukunan dalam Politik Indonesia. Universitas Bayangkara Jakarta Jaya: Jurnal Keamanan Nasional, Vol. 1, 2017.

[7] A. Marzuki, Nilai Pendidikan Islam dalam Tradisi Unan-Unan Masyarakat Suku Tengger. al-Murabbi, Volume 1, 2016.

[8] D. Harianto, Pengembangan Laboratorium Budaya Suku Tengger Untuk Mewujudkan Sistem Pemerintahan Desa yang Baik (Good Village Governance) Maksigama Jurnal Hukum, Thun, May, 2016.

[9] A.T. Subadyo, Arsitektur Pekarangan Suku Tengger di Kantung Taman Nasional Bromo Tengger Semeru. Prosiding Temu Ilmiah IPLBI. Pusat Studi Tata Lingkungan dan Bentang Alam, Jurusan Arsitektur Unmer Malang, 2016.

[10] S. Endraswara, Antropologi Wayang, Simbolisme, Mistisisme, dan Realisme Hidup. Yogyakarta: Murfalingua, 2017.

[11] H. Supratno, Haris. 2010. Sosilogi Seni, Wayang Sasak Lakon Dewi Rengganis dalam Konteks Perubahan Masyarakat di Lombok. Surabaya: Unesa University Press.

[12] (Interview with dalang Lebari, Wonomerso village, Kecamatan Sumber, Probolinggo, 2018).

[13] U. Eco, Teori Semiotika, Signifikasi Komunikasi, Teori Kode, Setra Teori Produksi-Tanda (Terjemahan Insiak Ridwan Munsir) . Bantul: Kreasi Wacana Offset, 2016.

[14] F. Merrell, Peirce, Signs, and Meaning. Toronto Buffalo London: University of Toronto Press, 1997.

[15] A. Robinson, God and the World of Signs: Trinity, Evolution, and the Metaphysical Semiotics of C.S.Peirce. Leiden. Boston: Brill, 2010.

[16] R. Nurfaidah, Adinda dalam Keterbacaan Simbol. Jurnal Bebasan, Vol.3, No.2, December, 2016.
[17] U. Eco, Teori Semiotika, Signifikasi Komunikasi, Teori Kode, Setra Teori Produksi-Tanda (Terjemahan Insiak Ridwan Munsir) . Bantul: Kreasi Wacana Offset, 2016.

[18] N. Sahid, Semiotika untuk Teater, Wayang, Wayang Purwa, dan Film. Semarang: Gigih Pustaka Mandiri, 2016.

[19] N. Sahid, Semiotika untuk Teater, Wayang, Wayang Purwa, dan Film. Semarang: Gigih Pustaka Mandiri, 2016.

[20] N. Sahid, Semiotika untuk Teater, Wayang, Wayang Purwa, dan Film. Semarang: Gigih Pustaka Mandiri, 2016.

[21] N. Sahid, Semiotika untuk Teater, Wayang, Wayang Purwa, dan Film. Semarang: Gigih Pustaka Mandiri, 2016.

[22] Interview with dalang Lebari, Wonokerto village, Sumber, Probolinggo, May, 2018.

[23] Teks Pertunjukan Wayang Topeng Tengger, "Lakon Behara Guru Krama" di Dusun Pojok , Desa Wonosari, Kecamatan Sumber, Probolinggo.

[24] N. Sahid, Semiotika untuk Teater, Wayang, Wayang Purwa, dan Film. Semarang: Gigih Pustaka Mandiri, 2016.

[25] Teks Pertunjukan Wayang Topeng Tengger, "Lakon Behara Guru Krama" di Dusun Pojok, Desa Wonosari, Kecamatan Sumber, Probolinggo.

[26] Teks Pertunjukan Wayang Topeng Tengger, "Lakon Behara Guru Krama" di Dusun Pojok , Desa Wonosari, Kecamatan Sumber, Probolinggo.

[27] Teks Pertunjukan Wayang Topeng Tengger, "Lakon Behara Guru Krama" di Dusun Pojok , Desa Wonosari, Kecamatan Sumber, Probolinggo.

[28] Teks Pertunjukan Wayang Topeng Tengger, "Lakon Behara Guru Krama" di Dusun Pojok , Desa Wonosari, Kecamatan Sumber, Probolinggo.

[29] Teks Pertunjukan Wayang Topeng Tengger, "Lakon Behara Guru Krama" di Dusun Pojok, Desa Wonosari, Kecamatan Sumber, Probolinggo.

[30] Teks Pertunjukan Wayang Topeng Tengger, "Lakon Behara Guru Krama" di Dusun Pojok , Desa Wonosari, Kecamatan Sumber, Probolinggo. 